
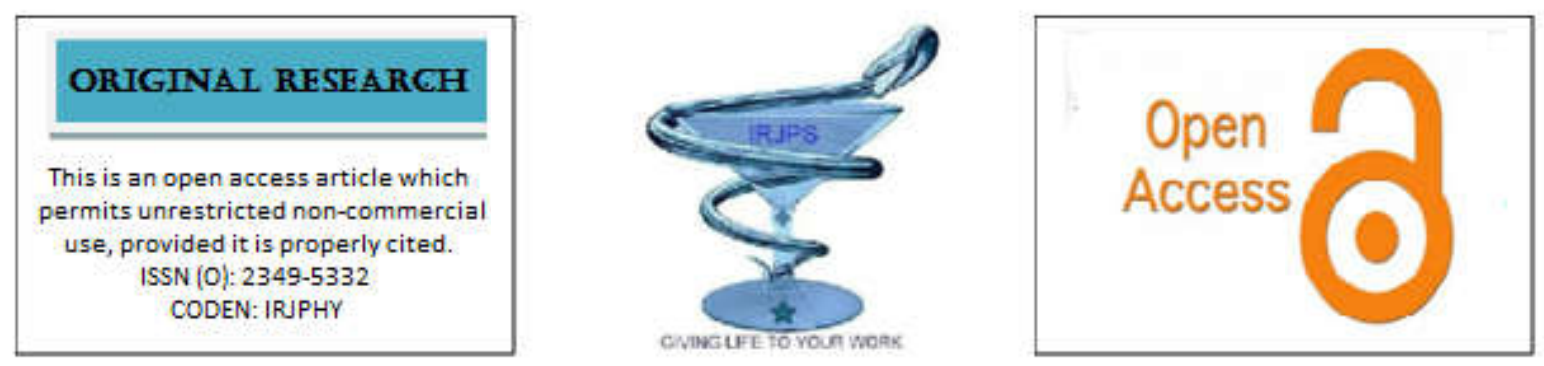

\title{
GCMS ANALYSIS AND EVALUATION OF THROMBOLYTIC ACTIVITY OF ESSENTIAL OIL OBTAINED FROM THE FLOWERS OF NYCTANTHES ARBOR TRISTISLINN.
}

\author{
Rasajna G*, Siva srinu K, Hemalalitha P, Bhanumahalakshmi P. \\ Department of pharmaceutical chemistry, Koringa college of pharmacy, Kakinada, East Godavari \\ Andhra Pradesh, India
}

Submitted on: 21.04.2020;

Revised on: 13.05.2020;

Accepted on: 19.05 .2020

\begin{abstract}
:
Objective: The objectives of this study were to identify the chemical composition of the essential obtained from the flowers of Nyctanthes arbor tristis and to carry out in vitro thrombolytic activity studies

Methods: the essential oil was obtained from the flowers of Nyctanthes arbor tristis by hydrodistillation and the chemical composition was determined by gas chromatography-mass spectrometry analysis. Thrombolytic activity was conducted using \%clot lysis assay using streptokinase as standard drug

Results: 11 compounds were identified in the essential oil in which betulin (26.58\%), (23.29\%) Undec-10-ynoic acid, undec-2-en-1-yl ester(23.29\%), were predominant followed by 1-propoxy propene (19.23\%), 9,17Octadecadienal (12.02\%), in clot lysis assay the essential oil showed \% clot lysis of 82.60, 86.36, 94.44, for $50 \mathrm{mg} / \mathrm{ml}, 100 \mathrm{mg} / \mathrm{ml}, 150 \mathrm{mg} / \mathrm{ml}$ respectively

\section{Conclusion:}

The chemical composition of essential oil reveals the presence of betulin in higher concentration which is known for its thrombolytic activity in the clot lysis assay and all the 11 compounds are being reported for the first time in Nyctanthes arbor tristis flowers which find their use in cosmetic industry. Therefore the flowers of Nyctanthes arbor tristis grown in yanam region can be a good source of fragrance for cosmetic industry
\end{abstract}

Keywords: Nyctanthes arbor tristis, \%clot lysis, gaschromatography- mass spectrometry

Corresponding Author: Rasajna G

E-mail: rasajnaguttala3011@gmail.com
Indian Research Journal of Pharmacy and Science; 25(2020)2121-2131;

Journal Home Page: https://www.irjps.in

DOI: 10.21276/irjps.2020.7.2.3 


\section{INTRODUCTION}

Nyctanthes arbor-tristis(NAT) Linn.is one of the well-known and most useful medicinal plant and belongs to Oleaceae. It is commonly called night jasmine in English, due to fact that its flowers emit a very strong and pleasant fragrance during whole night. NAT plant has been screened for antimalarial $^{(1)}$. antihistaminic, antiarthritis, local anesthetic, antihypnotic, analgesic ${ }^{[2]}$, antiulcer, antipyretic ${ }^{[3]}$, antidepressant, anti-leishmaniasis, anticancer ${ }^{[4]}$, antilarvicidal, antiallergic, antiviral ${ }^{[5]}$, immunomodulatory, antihelminthic ${ }^{[6]}$, antioxidant, antidiuretic activity, and as central nervous system modulators. NAT is said to have a wide range of medicinal benefits to humankind. The flowers of NAT are used in India, Indonesia (Java), and Malaysia to provoke menstruation while the bitter leaves are used as cholagogue, laxative, diaphoretic, and diuretic (Agroforestry tree database). The iridoidglucosides from NAT and identified the increased reactive oxygen species and cellular redox homeostasis imbalance in Leishmaniaparasite [7], to treat loss of appetite, piles, liver disorders, chronic fever, malarial fever, obstinate sciatica, rheumatism, and as a diaphoretic ${ }^{[1]}$. NAT is also known in Indian traditional medicine to possess immune toxic, antiallergic, antihistaminic, purgative, antibacterial, and ulcerogenic activities. Conventionally, the flowers of the plant are known to be effective as stomachic, carminative, astringent, antibilious, expectorant, and hair tonic and are used in the treatment of piles and various skin diseases. The bark is used to treat bronchitis and snakebite ${ }^{[8]}$. The present study is to identify the chemical constituents of the essential oil of the flowers of NAT Linn. and to carry out the thrombolytic activity using in-vitro clot lysis assay

\section{MATERIALS AND METHODS: PLANT MATERIAL:}

Nyctanthes arbor tristis flowers were collected from yanam surrounding areas and were authenticated by DrS.B.Padal Department of botany , Andhra university, Visakhapatnam. The collected flowers were taken to laboratory for distillation. ${ }^{[9]}$

\section{HYDRODISTILLATION OF FLOWERS:}

Fresh flowers(corolla) were hydrodistilled for $3 \mathrm{~h}$ using a Clevenger-type apparatus. The obtained essential oil was collected in a test tube. From the aqueous layer, petroleum ether was used to trap the essential oil. The trapped essential oil was dried using anhydrous $\mathrm{Na}_{2} \mathrm{SO}_{4}$ and the essential oil was recovered and stored at $4^{\circ} \mathrm{C}{ }^{[10]}$

\section{ANALYSIS OF THE ESSENTIAL OIL USING GAS CHROMATOGRAPHY-MASS SPECTROMETRY (GC-MS):}

The phytochemical investigation of NHE was performed on a GC-MS equipment schimadzu QP2010 plus Thermal Desorption system TD 20 Experimental conditions of GC-MS system were as follows: DB-5 MS capillary standard non-polar column, Flow rate of mobile phase (carrier gas: He) was set at $1.21 \mathrm{ml} / \mathrm{min}$. In the gas chromatography part, temperature programme(oven temperature) was $60^{\circ} \mathrm{C}$ raised to $280^{\circ} \mathrm{C}$ at $2^{\circ} \mathrm{C} / \mathrm{min}$ and injection volume was $1 \mu \mathrm{l}$. Samples dissolved in chloroform were run fully at a range of $40-650 \mathrm{~m} / \mathrm{z}$ and the results were compared by using Wiley Spectral library search and NSIT data libraries. The percentages of constituents were calculated leaving out the solvent peak as well as background peaks. 


\section{IN-VITRO CLOT LYSIS ASSAY:}

Essential oil from flowers of N.arbortristis was extracted using hydro distillation by clavenger apparatus and distilled water as solvent

Venous Blood was collected from four healthy volunteers for principal investigations

\section{PREPARATION OF ESSENTIAL OIL} SAMPLES:

The essential oil $(1 \mathrm{ml})$ extracted from flowers of N.arbortristis is dissolved in $10 \mathrm{ml}$ of normal saline to get $10 \mathrm{mg} / \mathrm{ml}$ solution

\section{BLOOD SPECIMEN:}

Venous blood samples were drawn from 4 healthy volunteers (age 22-24 years) without any recent history of oral contraceptive and anticoagulant therapy. About $0.3 \mathrm{ml}$ of blood was taken into each pre-weighed micro-centrifuge tube to form clots,

\section{PREPARATION OF POSITIVE CONTROL:}

To the commercially available lyophilized streptokinase $(15,00,000 \mathrm{IU})$ vial () $100 \mathrm{ml}$ of normal saline was added to adjust the concentration of streptokinase to $15,000 \mathrm{IU}$, which was used as the reference standard for thrombolytic activity since it is used as a common thrombolytic drug.

PROCEDURE OF IN-VITRO CLOT LYSIS ASSAY: ${ }^{[10]}$

Venous blood drawn from healthy volunteers $(n=$ 4)was immediately transferred in different preweighed sterile micro-centrifuge tubes, $0.3 \mathrm{ml}$ in each tube and then incubated at $37^{\circ} \mathrm{C}$ for $45 \mathrm{~min}$ for clotting to occur.

After clot formation, serum was completely removed (aspirated out without disturbing the clot formed) and each tube having clot was again weighed to determine the clot weight (clot weight $=$ weight of clot containing tube - weight of tube alone). Each microcentrifuge tube containing clot was properly labeled, and $1 \mathrm{ml}$ of each prepared concentration of the $\operatorname{NHE}(50,100,150 \mathrm{mg} / \mathrm{ml})$, normal saline (as a negative control), reference streptokinase were added to tubes with clots. All the tubes were incubated at $37^{\circ} \mathrm{C}$ for $90 \mathrm{~min}$. The fluid left was then carefully removed, and the tubes were weighed again. The difference in weight before and after clot lysis was expressed as percentage clot lysis.

\section{RESULTS AND DISCUSSION}

The various compounds present in the essential oil of Nyctanthes arbor tristis flowers was identified using Mass spectrometry attached with Gas chromatography(GC-MS) . the GC-MS chromatogram revealed the presence of a variety of components with various retention times

The components were eluted at different times indicating difference in their structure and nature. A large compound can split into smaller components due to which peaks appear at different $\mathrm{m} / \mathrm{z}$ ratios. The compounds corresponding to the peaks obtained from components were established from the data library. In the extract of Nyctanthes arbor tristis 11 bio molecules were identified and their molecular weight and formula determined 


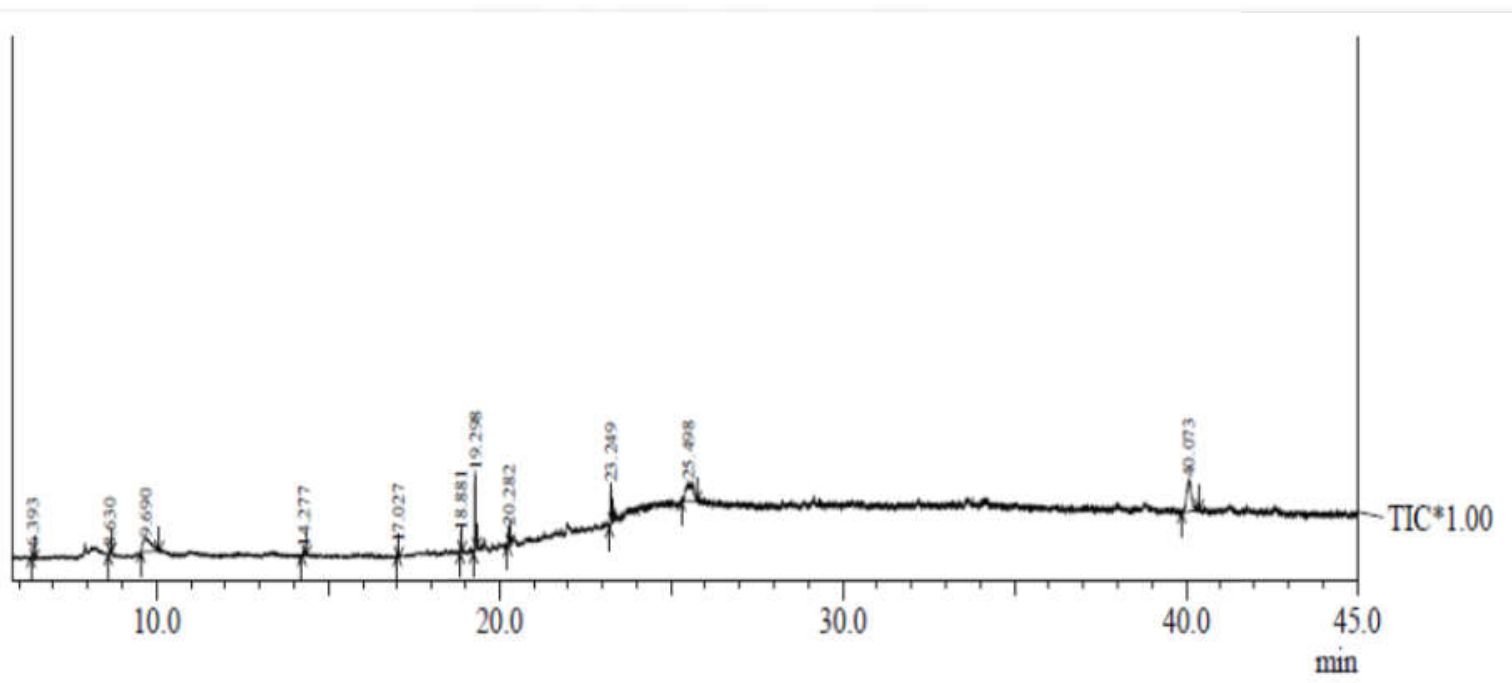

Fig no 1: GC-MS chromatogram of NHE

Table no 1: Retention time and peak areas of Peaks obtained in GCMS chromatogram of NHE

\begin{tabular}{|c|c|c|c|c|}
\hline Peak & Retention time & Peak area & Area \% & Compound name \\
\hline 1 & 6.393 & 21294 & 1.87 & 3-decen-2-one \\
\hline 2 & 8.630 & 11221 & 0.99 & 1-Pentanol, 4-methyl- \\
\hline 3 & 9.690 & 218760 & 19.23 & 1-propene, 1-propoxy-, (z)- \\
\hline 4 & 14.277 & 19023 & 1.67 & $\begin{array}{l}\text { 1,3-Dioxolane, } \\
\text { (phenylmethyl)- }\end{array}$ \\
\hline 5 & 17.027 & 13474 & 1.18 & $\begin{array}{l}\text { 1,2-Ethanediamine, } \mathrm{N}(1) \text {-phenyl- } \\
\mathrm{N}(2) \text {-(phenylmethyl)- }\end{array}$ \\
\hline 6 & 18.881 & 34225 & 3.01 & Piperidine, 4-methyl- \\
\hline 7 & 19.298 & 136613 & 12.01 & 9,17-octadecadienal, (z)- \\
\hline 8 & 20.282 & 41340 & 3.63 & (1,3-dimethyl-3- \\
\hline 9 & 23.249 & 74397 & 6.54 & 1,2-benzenedicarboxylic acid \\
\hline 10 & 25.498 & 265037 & 23.29 & $\begin{array}{l}\text { Undec-10-ynoic acid, undec-2- } \\
\text { en-1-yl ester }\end{array}$ \\
\hline 11 & 40.073 & 302448 & 26.58 & $\begin{array}{l}\text { Lup-20(29)-ene-3,28-diol, } \\
\text { (3.beta.)- }\end{array}$ \\
\hline & & 1137832 & 100.00 & \\
\hline
\end{tabular}


Out of the 11 bio molecules, 4 compounds namely 1propene, $\quad 1$-propoxy-, $\quad(\mathrm{z})-(\mathbf{1 9 . 2 3 \%}), 9,17-$ octadecadienal, (z)-(12.01\%), Undec-10-ynoic acid, undec-2-en-1-yl ester(23.29\%), Lup-20(29)-ene- 3,28-diol, (3.beta.)-(26.58\%)all these 11 biomolecules were reports for the first time in Nyctanthes arbor tristisflowers.

Table no 2: molecular formulae and molecular weights of compounds identified by GCMS in essential oil (NHE)

\begin{tabular}{|c|c|c|c|c|}
\hline S.NO & STRUCTURE & $\begin{array}{l}\text { Nature of the } \\
\text { compound }\end{array}$ & MOL WT & $\begin{array}{c}\text { MOL } \\
\text { FORMULA }\end{array}$ \\
\hline 1 & 3-DECEN-2-ONE & ketone & 154 & $\mathrm{C}_{10} \mathrm{H}_{18} \mathrm{O}$ \\
\hline 2 & 1-Pentanol, 4-methyl & alcohol & 102 & $\mathrm{C}_{6} \mathrm{H}_{14} \mathrm{O}$ \\
\hline 3 & 1-propene, 1-propoxy-, (z)- & ether & 100 & $\mathrm{C}_{0} \mathrm{H}_{12} \mathrm{O}$ \\
\hline 4 & 1,3-Dioxolane, 2-phenyl-2-(phenylmethyl) & $\begin{array}{l}\text { Heterocyclic } \\
\text { compound }\end{array}$ & 240 & $\mathrm{C}_{16} \mathrm{H}_{16} \mathrm{O}_{2}$ \\
\hline 5 & 1,2-Ethanediamine, $\mathrm{N}($ 1)-phenyl- $\mathrm{N}(2)$-(phenylmethyl)- & Aryl amine & 226 & $\mathrm{C}_{15} \mathrm{H}_{18} \mathrm{~N}_{2}$ \\
\hline
\end{tabular}




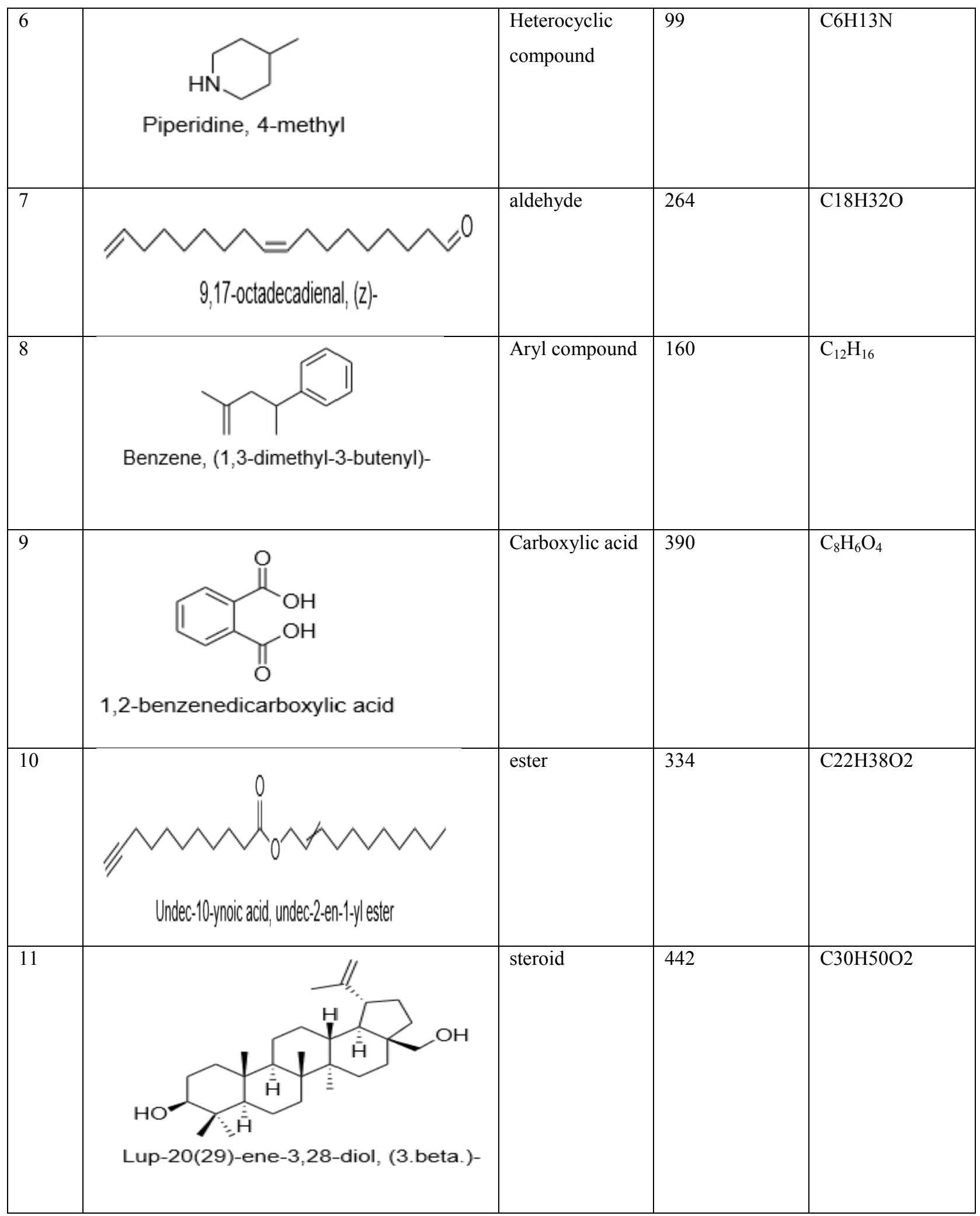


Table no 3: biological properties of compounds present in essential oil NHE

\begin{tabular}{|c|c|c|}
\hline Compound name & Sources & Uses \\
\hline 3-decen-2-one & Certain species of mushrooms & Flavouring agent in perfume industry \\
\hline 1-Pentanol, 4-methyl- & $\begin{array}{l}\text { Organic compound found in longan } \\
\text { fruit }\end{array}$ & Flavouring agent in perfume industry \\
\hline 1-propene, 1-propoxy-, (z)- & Organic compound & - \\
\hline $\begin{array}{l}\text { 1,3-Dioxolane, 2-phenyl-2- } \\
\text { (phenylmethyl)- }\end{array}$ & Found in apricot fruits & Flavouring agent (food grade) \\
\hline $\begin{array}{l}\text { 1,2-Ethanediamine, N(1)-phenyl- } \\
\mathrm{N}(2) \text {-(phenylmethyl)- }\end{array}$ & Organic compound & - \\
\hline Piperidine, 4-methyl- & Organic compound & $\begin{array}{l}\text { Used in synthesis of bioactive } \\
\text { compounds }\end{array}$ \\
\hline 9,17-octadecadienal, (z)- & $\begin{array}{l}\text { Lagenariabreviflora and } \\
\text { Solenaamplexicaulis }\end{array}$ & Flavouring agent in perfume industry \\
\hline Benzene, (1,3-dimethyl-3-butenyl)- & Seeds of Thevetiaperuviana & Flavouring agent \\
\hline 1,2-benzenedicarboxylic acid & Organic compound & $\begin{array}{l}\text { Used in synthesis of dyes, perfume, } \\
\text { saccharin, phthalates . }\end{array}$ \\
\hline $\begin{array}{l}\text { Undec-10-ynoic acid, undec-2-en-1- } \\
\text { yl ester }\end{array}$ & Castor oil & Treatment of skin problems \\
\hline Lup-20(29)-ene-3,28-diol, (3.beta.)- & Silver brich bark tree & $\begin{array}{l}\text { an antiviral agent, an analgesic, an } \\
\text { anti-inflammatory agent and an } \\
\text { antineoplastic agent, }\end{array}$ \\
\hline
\end{tabular}

THROMBOLYTIC ACTIVITY: The difference between weights of clots beforlysis and after lysis is measured and \%clot lysis was calculated using the formula

$$
\% \text { clot lysis }=\frac{(w t \text { of the clot before lysis }- \text { wt of the clot after lysis })}{w t \text { of the clot before lysis }} \times 100
$$


Table no 4: results of \% clot lysis activity

\begin{tabular}{|c|c|c|c|c|c|c|}
\hline Sample name & $\begin{array}{l}\text { Wt of CT } \\
\text { tube(A) }\end{array}$ & $\begin{array}{ll}\text { Wt of } & \text { CT } \\
\text { tube } & + \\
\operatorname{clot}(B) & \end{array}$ & $\begin{array}{l}\text { Wt } \quad \text { of } \\
\text { clot }=\text { B-A }\end{array}$ & $\begin{array}{l}\text { Wt of CT after } \\
90 \\
\text { incuhation(C) }\end{array}$ & $\begin{array}{l}\text { Wt of clot after } \\
\text { incubation(C- } \\
\text { A) }\end{array}$ & $\begin{array}{l}\text { \% of clot } \\
\text { lysis }\end{array}$ \\
\hline $\mathrm{NHE}_{50}$ & 0.91 & 1.14 & 0.23 & 1.10 & 0.04 & 82.60 \\
\hline $\mathrm{NHE}_{100}$ & 0.91 & 1.13 & 0.22 & 1.00 & 0.03 & 86.36 \\
\hline $\mathrm{NHE}_{150}$ & 0.91 & 1.09 & 0.18 & 1.08 & 0.01 & 94.44 \\
\hline $\mathrm{S}_{50}(+$ control $)$ & 0.91 & 1.06 & 0.12 & 1.05 & 0.01 & 91.66 \\
\hline $\mathrm{S}_{100}(+$ control $)$ & 0.91 & 1.06 & 0.13 & 1.05 & 0.01 & 92.30 \\
\hline $\mathrm{S}_{150}(+$ control $)$ & 0.91 & 1.06 & 0.15 & 1.0 & 0.01 & 93.33 \\
\hline
\end{tabular}

NHE = Nyctanthes arbor tristisflowers essential oil

$\mathrm{S}=$ positive control ( streptokinase)

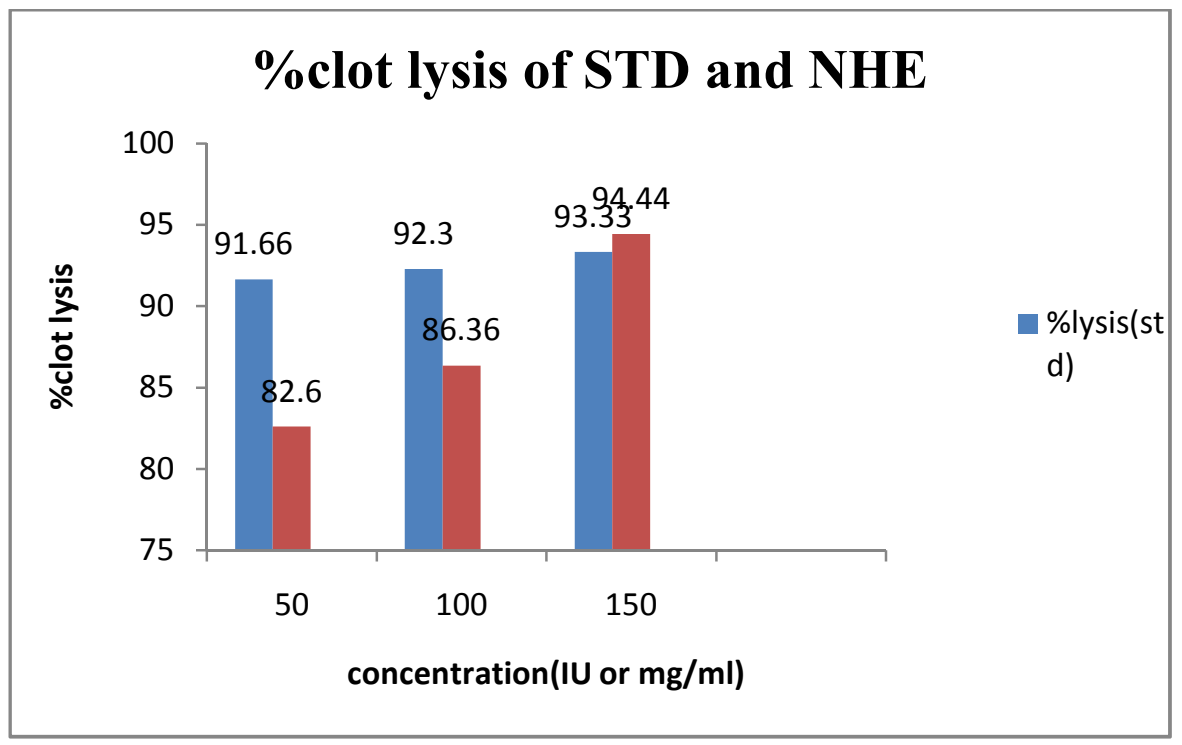

Fig 2 Percentage clot lysis 

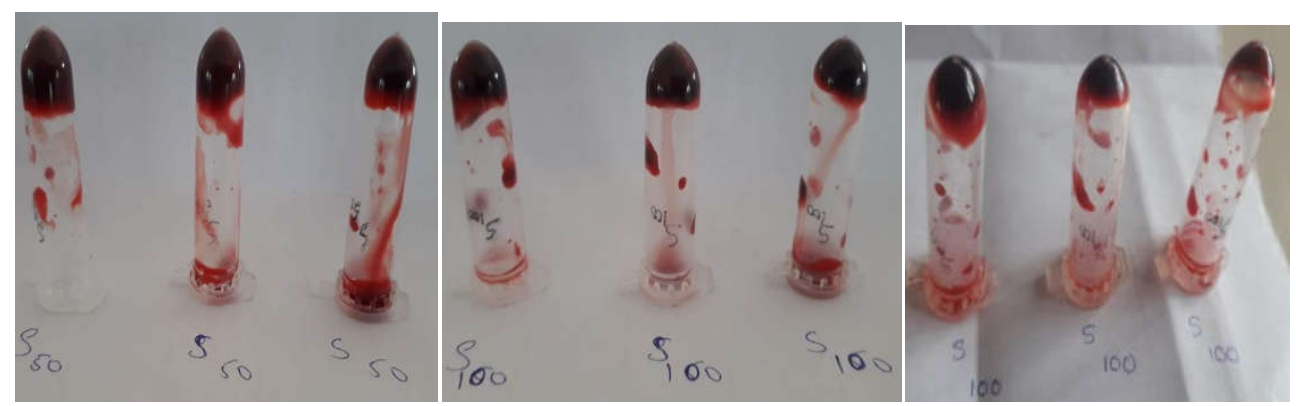

Fig no 3: Prepared clots for positive control

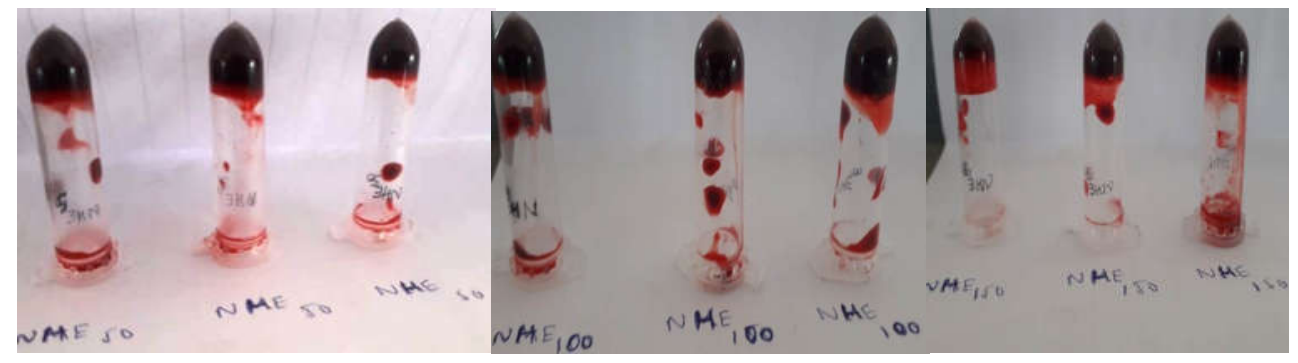

Fig no 4: Prepared clots for NHE
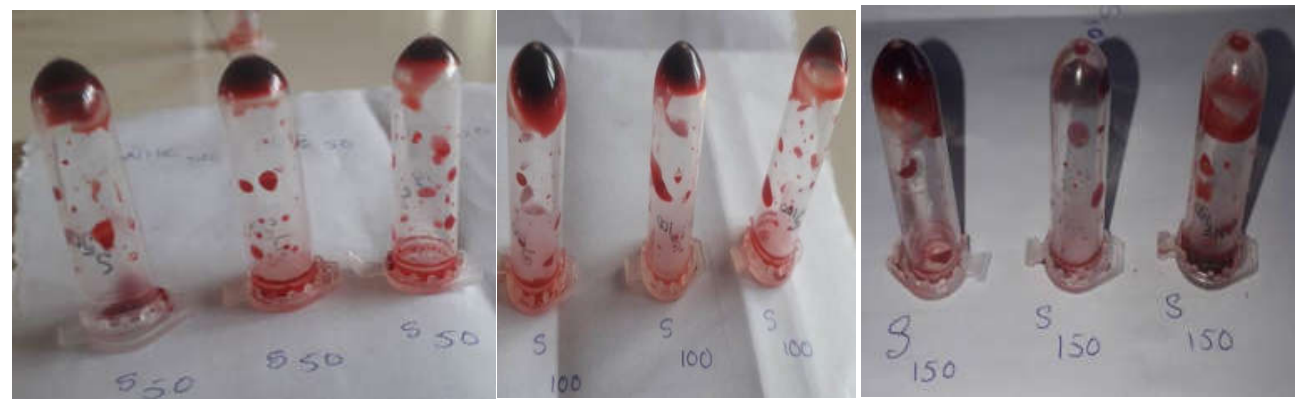

Fig no 5: Clots after lysis of positive control
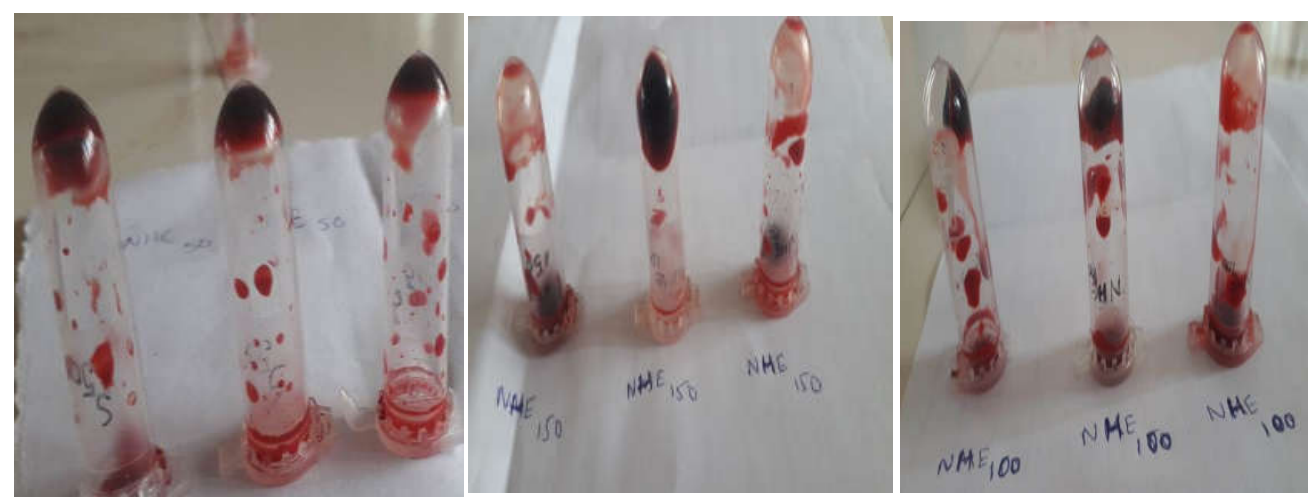

Fig no 6: Clots after lysis of NHE 


\section{CONCLUSION:}

GCMS study identified a total of 11 phytochemical constituents in the essential oil of Nyctanthes arbor tristis flowers in them 4 compounds namely 4 compounds namely 1-propene, 1-propoxy-, (z)(19.23\%),9,17-octadecadienal, (z)-(12.01\%), Undec10-ynoic acid, undec-2-en-1-yl ester(23.29\%), Lup20(29)-ene-3,28-diol, (3.beta.)-(26.58\%), are present in major amounts and all the 11 compounds identified are reported in Nyctanthes arbor tristis for the first time and their sources and pharmacological uses are mentioned in table no 6.4: all the compounds reported are presently in use as good flavouring agents in perfume industry from which it can be concluded that essential oil of Nyctanthes arbor tristis can be used in perfume industry.

From the results of thrombolytic activity it can be concluded that the essential oil from Nyctanthes arbor tristis flowers have more thrombolytic potential than that of standard taken(streptokinase), this is may be due to the presence of betulin which is a lupene derivative(Lup-20(29)-ene-3,28-diol, (3.beta.) is used in the treatment of atherosclerosis where it reduces the size of atherosclerotic plaques by inhibition of sterol regulatory element binding proteins(SREBP's).

So, further extraction and isolation of these phytochemicals can be useful in the treatment of atherosclerosis.

\section{ACKNOWLEDGEMENT:}

All the authors wish to express their sincere thanks to Ajai Kumar, Advanced Instrumentation Research Facility (AIRF), Jawaharlal Nehru University, and Delhi for GC-MS analysis.

\section{REFERENCES:}

1. Sah AK, Verma VK. Phytochemical and pharmacological potential of Nyctanthes arbor-tristis: A comprehensive review. Int J Res Pharm Biomed Sci 2012;3:420-7.

2. Nirmal SA, Pal SC, Mandal SC, Patil AN. Analgesic and anti-inflammatory activity of $\beta$-sitosterol isolated from Nyctanthes arbortristisleaves. Inflammopharmacology 2012;20:219-24.

3. Rani C, Chawala S, Mangat M, Mangal AK, Kajla S, Dhawan AK. Nyctanthes arbortristisLinn (Night Jasmine): A scared ornament plant with immense medicinal potentials. Ind $\mathrm{J}$ Traditional Knowledge 2012;11:427-35.

4. Kumari TD, Madhuri TD, Charya MA, Rao K. Antioxidant andanticancer activities of Nyctanthes arbor-tristis. Int J Pharm PharmSci 2012;4:452-4

5. Vyas S, Kachhwaha S, Kothari SL. Comparative analysis of the in vitro antioxidant activity and polyphenolic content of successive extracts of Nyctanthes arbor-tristisLinn. Int $\mathrm{J}$ Pharm PharmSci 2014;6:373-6

6. Sandhar HK, Kaur M, Kumar B, Prasher S. An update on Nyctanthes arbor-tristisLinn. Int Pharm Sci 2011;1:77-86.

7. Kumari TD, Charya MA. Docking studies on bioactive compounds of Nyctanthes arbor-tristis. Int $\mathrm{J}$ Pharm PharmSci 2016;8:361-5.

8. Agrawal J, Pal A. Nyctanthes arbortristisLinn a critical ethnopharmacological review. J Ethnopharmacol 2013;146:645-5 
9. Karthick v, venkatareddy g, dharani j, and ravi s. "study on the chemical constituents of the essential oil from nyctanthes arbortristis and its molecular docking studies". Asian Journal of Pharmaceutical and Clinical Research, Vol. 12, no. 5, Apr. 2019, pp. 195-9
10. Hussain, Fahad et al. "In vitro thrombolytic potential of root extracts of four medicinal plants available in Bangladesh." Ancient science of life vol. 33,3 (2014): 162-4. doi:10.4103/0257-7941.144620

CONFLICT OF INTEREST REPORTED: NIL ; SOURCE OF FUNDING: NONE REPORTED 